\title{
Leading and education of talented employees as one of the major impacts of globalization on human resources management
}

\author{
Luba Tomcikova ${ }^{1, *}$, Jana Coculova ${ }^{2}$ \\ ${ }^{1}$ University of Presov, Faculty of management, Konštantínova 16, 08001 Presov, Slovakia \\ ${ }^{2}$ University of Presov, Faculty of management, Konštantínova 16, 08001 Presov, Slovakia
}

\begin{abstract}
Human resources and knowledge play an important role in the today's fast-changing world. Human resource optimization is achieved when human resources are aligned with key organizational initiatives to maximize business performance. Talented people are the future of every business. Leading and developing the potential of talented employees should be on the agenda of every modern business. Businesses that know what globalization brings try to attract talented people as talented people are playing an increasingly important role in all sectors, thus confirming that talent management is becoming the fastest growing global human resource management trend. Many businesses realize that they must relocate their business, sometimes even across borders, to succeed. Working with talent must be a top priority for businesses, as talent needs to be constantly developed and managed. The aim of the paper is to define the basic concepts related to the acquisition, management and development of talents at the theoretical level and to point out the importance of talent management as it is becoming an important global trend. Based on the survey we carried out and literature available, the main objective of the paper is to identify key roles and responsibilities that talented employees take upon, to specify a set of requirements placed upon talented employees and to identify factors determining the ability of a business to attract talents.
\end{abstract}

\section{Basic theoretical background of the researched issue}

The current turbulent time is characterized by constant market changes, globalization, internationalization, financial market volatility, rapid technological and technological developments in various sectors, new marketing approaches, and different trends in society. However, all these changes and processes are conditioned by one common fundamental fact, namely that all innovations, process management, management of all input sources, whether financial, information, material, their control, correction, coordination, planning and organization could not exist without one important factor, which is human capitalgreat talented staff with enough autonomy and enough resources to create new innovative

\footnotetext{
*Corresponding author: luba.tomcikova@unipo.sk
} 
ideas. The importance of human capital is also evidenced by a study conducted by Delloite entitled "Aligned of The Top. How business and HR executives View Today's Most Significant People Challenges" where up to $85 \%$ of respondents (companies) confirmed the fundamental influence of their employees on achieving the required performance and the set goals, as well as progress in the business of their company [1]. Investments in frameworks for recruiting, retaining and developing the best talent can bring a significant competitive advantage and help businesses meet their goals. Harsch, Festing [2] present that today's business environment is becoming increasingly dynamic and the concept of agility is gaining attention in the corporate world. Developing and retaining talent is crucial in helping organizations compete effectively. However, how employers understand talent and thus invest appropriate resources to motivate and develop talented employees still requires considerable attention [3].

Stýblo [4] points out that it is the leadership and training of talents that are becoming one of the most important factors in human resource management. Brink, Fruytier, Thunnissen [5] present that a key of global human resources management are talent employees and performance management. Eyre [6] also confirms that talent management is the biggest human resource management challenge for organizations today and will remains so in the near future. At the same time, he states that organizations operating under the influence of globalization are attracting talented people who are playing an increasingly important role in all sectors, confirming that talent management is thus becoming the fastest growing global trend in human resources management. Many organizations realize that in order to succeed, they need to move their business activities to new locations, or possibly beyond national borders. Authors Collings, Mellahi, Cascio [7] develop a theoretical framework for how global talent management links to performance at the headquarters, subsidiary, and individual employee levels. Allen, Lee, Reiche [8] present that within the fields of international business and human resources management, global work, strategic human resources management, and global talent management have thus far remained largely separate research streams. Talent management has become a challenge to all the organizations in a global context irrespective of the country [9]. Furthermore the anxiety for the scarcity of the talent is a universal issue. All organizations around the globe are competing for the same talent. Global integration trend show the standardization in talent recruitment, management and development to make sure their competitive advantage in the market [10]. Authors Dundon and Rafferty [11] point out the importance of reward strategies, talent management, and high performance work systems in human resources management in a global work environment. Talent management describes an organization's identification of key positions and, subsequently, the development and retention of a talent pool to fill those positions [12]. Talent management is increasingly important to organizational leaders who are attempting to maximize their business performance, with the central assumption that it is essential to recruit, develop, and retain 'top' employees in order to meet the strategic business objectives of organizations [13].

The results of a survey conducted by King's College London [14] which shows that talent management will be a huge challenge for domestic as well as foreign business organizations over the coming years. At the same time, we can say that talent management is becoming the focus of perhaps all companies that think about their future. In the context of talent management, high-potential employees and key talents are discussed. These two terms are described in the publication "Managing talent across a global workforce" by Woollard [14] who states that when we talk about "high-potential" employees, we mean people with considerable potential and fast-paced careers. The author also points out these facts:

Organizations or businesses that are under the influence of globalization must have appropriate career development plans for the global workforce. 
- As regards talent management in an international context, organizations will only seek to identify and develop "key global talents".

- In a difficult economic environment, given the constraints on financial and other resources, organizations cannot afford to manage and develop all of their personnel within the organization. It is therefore logical that they will focus only on a smaller number of high-performing and exceptional people with high potential.

There are a lot of challenges in this regard, such as:

- How to identify key talents?

- How to identify key tasks that they should accomplish?

- What potential should they have at the beginning?

- How to manage talent effectively? [15]

In the context of the advancing globalization, we can say that the success of any organization or every business lies in their work with talent. Some foreign experts [4] recommend the following:

- $\quad$ Talents must be distinguished by ability, not by age; search, development and evaluation of competent employees must always be the same regardless of age.

- $\quad$ More experience does not mean less ability. Experienced employees play a stabilizing role in companies.

- Talents need to be identified and developed from own resources. There are companies who believe that newly recruited employees will be of great benefit to the company and will therefore replace a significant proportion of staff in connection with their innovation policies. However, such an approach may become an obstacle to HR and to the overall development of their potential.

- Emphasis is placed on professional abilities. If employees see the possibility of career advancement and professional growth regardless of their age, they get new powers and motivation to work and thus they are more efficient.

- $\quad$ Managers and HR specialists play an irreplaceable role in the work with talent. They act as consultants and organize in-house workshops, trainings, evaluation interviews in the preparation of career plans and the like.

- In every business, it is extremely important to collect, track and review talent data. It allows businesses to catch up in time and respond to the risk of disproportionate talent departure or detect lack of successors.

According to Thorne and Pellant [16] a talent is a talented person who has more exceptional abilities than others and has a certain charisma given by abilities others try to imitate or from which they draw inspiration. The authors also mention characteristics and abilities such as focus on performance, emotional flexibility, self-knowledge, optimism, self-confidence, pragmatism, autonomy and the like. Cannon and McGee [17] published one of the most common definitions of talent. According to them, talent is an individual who delivers high performance and has great potential for the future, which makes it easier for companies to develop a plan of succession. Generally, it is assumed that global talent management means the strategic integration of resourcing and development at the international level which involves the proactive identification and development and strategic deployment of high-performing and high-potential strategic employees on a global scale [18]. Talent management is a corporate buzzword that has become a priority of boards of directors, HR managers and recruitment agencies alike. We believe that amidst all of the noise and activity some critical questioning regarding the ethical implications of all the buzz around 'talent' is much needed [19]. Cannon and McGee [17] are of the opinion that talent management activities are nothing new in the field of personnel management and many talent management activities were performed before the concept itself was even developed. They say, however, that these activities have been framed in such a form and 
structures whose coordination and combination created a great concept to help businesses differentiate and, in particular, to gain a competitive advantage. Armstrong [20] agrees with this idea, but points out that activities such as acquisition, retention (stabilization), motivation and engagement, development and succession planning are interconnected and aligned in the concept to form a cohesive whole that really helps to maintain and acquire the best talents. Recruiting influences talents employees' motivation, performance, and retention. Because an organization's talent influences its capabilities, strategic execution, and competitive advantage [21]. According to Horváthová [1], the overall strategy of talent management, which is linked to the strategy of the whole company, will result in three groups of processes leading to the achievement of the set goals in the field of talent management and creation of the talent pool of the company. Specifically, the process involves acquisition, development and retention of talent, and each of these areas contains many activities. Strategic talent management should align and mutually reinforce business development and personal development to enhance strategic succes [22].

As far as talent management is concerned, it can be stated that having the best program for talents is not enough if there is a lack of a clear goal as the desired effect will not be reached. Without a well-defined talent management strategy, we cannot choose the right people, not even prepare an appropriate program that would outline how to work with them. As Stýblo [4] states: "In practice, there is nothing worse than having talents and not working with them, or working with them incorrectly." Because as Mohrman [23] states, we live at a time characterized by a lack of talents, at a time when personal functions are naturally improved, and the main task of which is to attract and develop new talents with new knowledge and skills. Cannon and McGee [17] provide a talent acquisition strategy that is summarized in the following Table 1.

Table 1. Talent Acquisition Strategies

\begin{tabular}{|l|l|l|}
\hline Strategy & When to use the strategy & $\begin{array}{l}\text { Possible risks of using the } \\
\text { strategy }\end{array}$ \\
\hline $\begin{array}{l}\text { Former employee } \\
\text { Keeping in touch with people } \\
\text { who left the organization }\end{array}$ & $\begin{array}{l}\text { When recruiting or looking for } \\
\text { an employee to stand in for } \\
\text { someone temporarily }\end{array}$ & $\begin{array}{l}\text { This may be a source of } \\
\text { dissatisfaction in other } \\
\text { employees if there are } \\
\text { differences in remuneration. }\end{array}$ \\
\hline $\begin{array}{l}\text { Opportunistic acquisition } \\
\text { The goal is to acquire talent the } \\
\text { moment we discover it in order to } \\
\text { fill the talent pool }\end{array}$ & $\begin{array}{l}\text { When talent is a rare item on } \\
\text { the market. Ideally, there are } \\
\text { high-quality candidates ready } \\
\text { to work immediately }\end{array}$ & $\begin{array}{l}\text { Cost control } \\
\text { Finding out how well a } \\
\text { company knows its future } \\
\text { needs }\end{array}$ \\
\hline $\begin{array}{l}\text { Part-time job opportunities } \\
\text { Creating a network of proven and } \\
\text { reliable staff resources }\end{array}$ & $\begin{array}{l}\text { If there are short-term needs } \\
\text { or fluctuations in HR } \\
\text { requirements }\end{array}$ & $\begin{array}{l}\text { If this is done for a very long } \\
\text { period, the cost can be high }\end{array}$ \\
\hline $\begin{array}{l}\text { Offshoring/outsourcing } \\
\text { Conclusion of contract with } \\
\text { external suppliers }\end{array}$ & $\begin{array}{l}\text { If there is a substantial price } \\
\text { advantage }\end{array}$ & Hidden cost of training \\
\hline $\begin{array}{l}\text { Versatile temporary teams } \\
\text { Temporary transfer of employees } \\
\text { to teams from their existing roles }\end{array}$ & $\begin{array}{l}\text { In order to solve } \\
\text { organizational problems in } \\
\text { crisis situations in terms of } \\
\text { personnel. }\end{array}$ & $\begin{array}{l}\text { It may happen that the } \\
\text { participants are so satisfied } \\
\text { with the team that they do not } \\
\text { want to return to their original } \\
\text { position }\end{array}$ \\
\hline
\end{tabular}

\section{Material and methods}

The main aim of this paper was to identify and point out the importance of key tasks, responsibilities and competences that talented employees should have in the current globalized business environment, and to specify a set of characteristics/requirements placed 
on talented employees and identify factors that determine the ability of an enterprise to attract talents. The survey sample consisted of 112 respondents (managers at different management levels), whose responses were the subject of primary data collection. The questionnaire survey targeted companies operating mainly in the area of information and communication technologies (ICT) in the Slovak Republic. Of the total of 112 managers, top managers accounted for $29.46 \%$ of the research sample, middle management accounted for $26.79 \%$ and managers at the lowest levels accounted for $43.75 \%$ (a total of 49 respondents).

\section{Results and discussion}

Talented employees need to be developed, cared for, educated and motivated to strengthen their loyalty and engagement, giving them the opportunity to acquire skills that would help them advance their career. Talented employees should be supported and rewarded through various development programs and should be given the opportunity to work on special projects to show off their quality. It is necessary to develop their strengths as well as their overall performance, boost their motivation and enable career advancement. The aim of the questionnaire survey is to identify key roles, responsibilities and competences of talented employees in the current business environment. By asking managers at different levels of management working in the field of ICT, we tried to find out which competencies are, from their point of view, key/most important for talented employees. The first task was to identify the competences and tasks that a talented employee should have. Based on literature research, the competences referred to by Berger and Berger [24] are the ones that are crucial for our research: orientation on activity, communication, creativity and innovation, critical judgment, interpersonal skills, leadership, teamwork, technical and functional qualification, customer orientation. Respondents evaluated the above competencies on the Likert scale from 1-5, where 1 represents the most important competence and 5 the least important competence. We can say that each of the competencies is extremely important for every employee and, above all, key for talents. The most important competence is creativity and innovation (97 respondents identified scale 5). With talented employees, it is very important to evaluate their performance and predict their potential. Cannon and McGee [17] provide the characteristics of such an individual. They point out the following characteristics: the employee has the respect and trust of subordinates, employees at the same level as well as the superiors; is the implementer of changes in the enterprise; is a creative thinker, a solver of non-routine problems; has a great capacity to learn and develop; is open to feedback and criticism that can move him/her forward; is highly competent in his field.

One of the tasks was to point out the key tasks of talented employees which increase the performance of employees and which may help them advance their career in the company. Cannon and McGee [17] characterize roles and responsibilities of an individual that help enhance an individual's performance as follows: consistently deliver measurable performance that exceeds expectations; manage oneself in a way that promotes learning and high performance; ensure that team goals are achieved; manage teams that give a sense of loyalty; strive to meet customers' needs even beyond their requirements; work effectively with enterprise resources; and high resistance. The aim was to select the three most key tasks from the respondent's point of view. In the research carried out, the largest number of managers from all levels of management identified the most crucial task to be the following - to manage oneself in a way that promotes learning and high performance, accounting to a total of $70.53 \%$ of respondents. Other tasks include: working efficiently with company resources $(65.5 \%$ of respondents) and ensuring that team goals are achieved $(58.04 \%$ of respondents). 
Different tasks require different talents. While experience, intelligence and willpower significantly affect performance, only the presence of real talents can affect performance. Only the presence of talents can explain why, when all other factors are the same, some people excel while others struggle. Based on the results of the questionnaire survey, a set of characteristics of talents was drawn up. Based on the average values of respondents' answers, the following set of the most important characteristics was compiled. Talented employee should have or be (outlined values represent average values on the basis of which the ranking from the most important characteristics to the least significant was drawn up): The need to take personal responsibility for his work $(1,10)$; Ability to manage $(1,10)$, Ability to take over a task $(1,10)$; The need to be objective and measure performance $(1,20)$; Ability to use emotions to overcome resistance $(1,25)$, Ability to act in various possible scenarios in the future (1.27); Ability to identify the feelings and perspectives of others $(1,30)$; The need to invest in others and capitalize on that $(1,35)$; The need to look at things from the bright side $(1,37)$; The need to build a sense of mutual support $(1,75)$; Physical endurance $(1,80)$, The need to assess success by comparison $(1,90)$; Initiative to put his beliefs into practice $(2,00)$; Initiative to be useful to others $(2,00)$; The need to obtain the consent of others $(2,10)$, The need to build long-term relationships $(2,35)$.

One of the most important partial goals of the research was to identify the factors determining the company's ability to attract talented employees. The main task was to find out which of the factors influence the ability of companies to attract talents from the perspective of respondents/managers the most. The goal of a company in the process of maintaining and managing talents is for talented individuals to remain in the company as loyal and faithful employees committed to work, without the intention to leave the company. Horváthová [1] states that if companies want to retain these key talented employees, it is essential that they become a high-quality employer. In doing so, companies my consider the following:

An interesting and rewarding job: talented employees must be given an interesting job that is directly related to their interests and which is still a challenge for them.

- Offering opportunities for career development and further training: the development and education of employees is very important, as they move forward not only for the company' sake but also for their own.

- Maintaining a work-life balance: talented employees are interested in jobs that follow their lifestyles.

- Flexible role in the company: the role performed by a talented employee should include responsibility, incentive and autonomy which also gives space for learning as well as innovative ideas.

- Quality working conditions and facilities is a factor that helps retain employees and encourage them to perform better.

- Creating a sense of recognition and respect: the company should support the culture of recognition of one's work and outcomes, thus distinguishing itself from among the competition and ensure that talented employees are satisfied and remain in the company.

- Directly proportional remuneration: nowadays, salary is not everything as employee benefits such as non-financial remuneration, flexible working hours, teleworking, career breaks, various programs and training paid for by the company, care for older family members are gaining increasing weight among employees.

- Social responsibility of the company: talented employees want to be part of a company that creates values other than profit and supports the region and local 
community, promotes environmental initiatives, and created feeling that employees are part of "something bigger".

Respondents evaluated determinants such as the quality of working conditions and facilities, working with the latest technologies, opportunities for growth and development, prestige of the company, attractive corporate culture, flexible working hours, employee benefits and benefits, and others. The question about the determinants of attractiveness is very important, as it will help us find out what factors are crucial for attracting and retaining talented employees in the companies surveyed. Managers had the opportunity to rate the items of the questionnaire on the Likert scale from 1-5, where 1 is the most important factor determining the ability of a company to attract talented employees and 5 is the least important factor determining the ability of a company to attract talented employees. Based on the results of the questionnaire survey, a table was prepared that presents the average values of respondents' answers (Table 2).

Table 2. Average values of the importance of factors determining the ability of a company to attract talented employees.

\begin{tabular}{|l|c|}
\hline Factors determining the ability of a company to attract talents & Average \\
\hline Possibility to do fulfilling and meaningful work & 1,10 \\
\hline Possibility to grow and develop one's potential & 1,20 \\
\hline Good social and interpersonal relationships at the workplace & 1,50 \\
\hline Perspective of possible career growth & 1,85 \\
\hline Perspective of possible wage growth & 1,85 \\
\hline Quality working conditions and facilities & 1,90 \\
\hline Employee benefits and benefits & 1,90 \\
\hline Flexible working time & 1,95 \\
\hline Work-life balance & 2,10 \\
\hline Possibility of being creative & 2,10 \\
\hline Company's prestige & 2,15 \\
\hline Work with the latest technologies & 2,15 \\
\hline Attractive corporate culture & 2,30 \\
\hline
\end{tabular}

Source: authors

In connection with the above objectives, a scientific research hypothesis was formulated the aim of which was to test the statistically significant differences in the perception of the importance of individual determinants of the ability of a company to attract talented employees among managers at different management levels. The hypothesis was tested using pivot tables and statistical methods. As for the inductive statistics method, we used the Chi-square goodness of fit to test the zero statistical hypothesis, which claims that the frequencies in each category are equal to those expected (theoretical frequencies). If the pvalue is lower than the selected significance level (traditionally $5 \%=0.05$ ), the null hypothesis is rejected. This means that the difference between the frequencies found in the sample and the expected frequencies is too large to be the result of random sampling, i.e. it is statistically significant. If the p-value is equal to or higher than the selected significance level, the null hypothesis cannot be rejected. This means that the difference between the frequencies found in the sample and the expected frequencies may be due to random sampling, i.e. it is not statistically significant. The aim of the null hypothesis is to find out whether there is or there is no difference between obtained and expected ratios. The null hypothesis ( $\mathrm{H} 0)$ assumes that there is no difference between expected and theoretical results. The formulated hypothesis is as follows:

H1: There are statistically significant differences in the perception of the importance of individual factors determining the ability of a company to attract talents from among managers at different levels of business management. 
The result of the Chi-Square test came at 51.803 at a significance level of 0.05 , with a pvalue of 0.000 . Based on these results, we can state that we accept the hypothesis and confirm the existence of statistically significant differences in the perception of the importance of individual determinants of the ability of a company to attract talented employees from among top, middle and lower management.

\section{Conclusion}

Although companies have already been using some talent management tools, these were irregular and random. With the advent of talent management came a solid system of tools that can give companies various advantages in the market. Essentially, talent management processes are at the core of the system, they are what holds the company together and give it a solid advantage on the market. Companies operating in the global market should now realize that success in the field of talent management is not based on how many talents and what talents they will gain in competition with other organizations (external resources), but mainly on how they manage talents they already have (internal resources), how they motivate and develop them, how they care for them and whether they retain them. Several authors such as Armstrong [20], Horváthová [1] highlight the most important factors for retaining talented employees such as possibility of career advancement/ growth, interesting tasks and providing opportunities for development and training. Cannon and McGee [17] highlight talent management and report that those companies that neglect talent management in today's highly competitive business environment, where knowledge is one of the driving forces, are putting themselves at risk. If businesses want to win talent in the current highly competitive environment, they should create an attractive bonus and reward system for employees, provide interesting work experience, training and personal leadership programs that would develop the potential of talented employees.

Scientific Paper was elaborated within the framework of the projects KEGA 012PU4/2019. Elaboration of educational materials for the newly introduced subject "Talent management"

\section{References}

1. P. Horvathova, Talent management (Wolters Kluwer, Praha 2011)

2. K. Harsch, M. Festing, Dynamic talent management capabilities and organizational agility- A qualitative exploration, Human resources management (2019)

3. S-Y. Chen, A.Y. Lee, D. Ahlstrom, Strategic talent management systems and employee behaviors: the mediating effect of calling, Asia Pacific Journal of Human resources (2019)

4. J. Stýblo, Management podniku světové tř́dy (Praha, Professional Publishing, 2010)

5. M. Brink, B. Fruytier, M. Thunnissen, Talent management in academia: performance systems and HRM policies, Human resources management Journal 23, 2 (2012)

6. E. Eyre, Managing talent is top global HRM challenge, Training Journal (2008)

7. D.G. Collings, K. Mellahi, W.F. Cascio, Global talent management and performance in multinational enterprises : a multilevel perspectives, Journal of management 45, 2 (2018) 
8. D. Allen, Y. Lee, S. Reiche, Global work in the multinational enterprise: New avenues and challenges for strategically managing human capital across borders, Journal of Management 41, 7 (2015)

9. T.M. Gardner, In the trenches at the talent wars: competitive interaction for scarce human resources, Human Resources Management, 41 (2002)

10. F. Rabbi, Talent management as a source of competitive advantage, Journal of Asian business strategy 5, 9 (2015).

11. T. Dundon, A. Rafferty, The potencial demise of HRM ? Human resources management Journal 28, 3 (2018)

12. M. Crowley-Henry, E.T. Benson, A.A. Ariss, Linking Talent Management to Traditional and Boundaryless Career Orientations: Research Propositions and Future Directions, European Management Review 16, 1 (2018)

13. G. De Boeck, M. C. Meyers, N. Dries, Employee reactions to talent management: Assumptions versus evidence, Journal of Organizational Behavior 39 (2018)

14. S. Woollard, Managing talent across a global workforce, Stategic HR Review 9, 5 (2010)

15. M. Ehrnrooth et al., Talent responses to talent status awareness - Not a question of simple reciprocation, Human resources management Journal 28, 3 (2018)

16. J. Thorne, A. Pellant, Develop and motivate of employees (Computer Press, Brno, 2007)

17. J.A. Cannon, R. McGee, Talent management and succession planning (CIPD, London, 2007)

18. A. Pachura, Talents, projects and management-attempt at synthesis, Polish Journal of management Studies 19, 1 (2019)

19. M. Painter-Morland et al. Talent Management: The Good, the Bad, and the Possible, European Management Review 16, 1 (2018)

20. M. Armstrong, Human resources management (Grada Publishing, Praha, 2007)

21. J.M. Phillips, S.M. Gully. Multilevel and Strategic Recruiting: Where Have We Been, Where Can We Go From Here? Journal of Management 41, 5 (2015)

22. R. Schreuder, S. Noorman, Strategic talent management: creating strategic value by placing top talents in key positions, Development and learning in organizations, International Journal 33, 1 (2019).

23. S.A. Mohrman, Designing ogranizations for growth: The Human resources contribution, Employ Respons Rights Journal 19 (2007)

24. L.A. Berger, D.R. Berger, Talent management handbook: Creating organizational excelence by identifying and promoting your best people (McGraw-Hill, New York, 2003) 